\title{
Ointment Dosage Form
}

National Cancer Institute

\section{Source}

National Cancer Institute. Ointment Dosage Form. NCI Thesaurus. Code C42966.

A semi-solid, viscous in texture, that may be composed of a variety of bases including hydrocarbons, emulsifiers or vegetable oils, and mixed with active and/or inert ing redient(s). 